\title{
Central injection of captopril inhibits the blood pressure response to intracerebroventricular choline
}

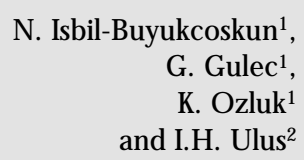

Departments of ${ }^{1}$ Physiology and 2 Pharmacology,

Uludag University M edical Faculty, Gorukle, Bursa, Turkey

\section{Correspondence \\ N. Isbil-Buyukcoskun \\ Department of Physiology \\ Uludag University Medical Faculty \\ 16059, Gorukle, Bursa \\ Turkey \\ Fax: + 90-224-442-8832 \\ E-mail: guldal@ uludag.edu.tr}

Received June 20, 2000

Accepted February 13, 2001

\section{Abstract}

In the present study, we investigated the involvement of the brain renin-angiotensin system in the effects of central cholinergic stimulation on blood pressure in conscious, freely moving normotensive rats. In the first step, we determined the effects of intracerebroventricular (icv) choline $(50,100$ and $150 \mu \mathrm{g})$ on blood pressure. Choline increased blood pressure in a dose-dependent manner. In order to investigate the effects of brain renin-angiotensin system blockade on blood pressure increase induced by choline $(150 \mu \mathrm{g}, \mathrm{icv})$, an angiotensin-converting enzyme inhibitor, captopril ( 25 and $50 \mu \mathrm{g}, i c v)$, was administered $3 \mathrm{~min}$ before choline. Twenty-five $\mu \mathrm{g}$ captopril did not block the pressor effect of choline, while $50 \mu \mathrm{g}$ captopril blocked it significantly. Our results suggest that the central renin-angiotensin system may participate in the increase in blood pressure induced by icv choline in normotensive rats.

\section{Introduction}

Central cholinergic neurons and cholinergic receptors are involved in cardiovascular regulation (1-6). It has been shown that intracerebroventricularly (icv) injected choline increases blood pressure and decreases heart rate in conscious, freely moving, normotensive rats $(2,4,6)$. In a number of studies, it has been reported that the effects of cholinomimetics on the cardiovascular system are mediated by central muscarinic $(1,5)$ or both nicotinic and muscarinic receptor activation (6), which results in the activation of the sympathoadrenergic system $(5,6)$. The vasopressinergic system also mediates the effects of choline on blood pressure. Cen- trally injected acetylcholine and several other cholinergic agents have been shown to increase vasopressin (VP) secretion (6-8).

Another system involved in blood pressure regulation is the renin-angiotensin system (9-11). All elements of the renin-angiotensin system have been identified in brain tissue (12-15). Central angiotensin II (Ang II) increases arterial blood pressure, stimulates drinking behavior, increases VP and corticotropin secretion and inhibits renin secretion (12,16-21). The effect of central Ang II on heart rate is controversial. Investigators have found that centrally injected Ang II decreases, increases or does not affect heart rate (18,22-27). The central effects of Ang II on blood pressure are mediated by an in- 
crease in sympathetic tone and depend on the integrity of central catecholaminergic neurons $(9,10)$.

Arslan et al. (6) and Ulus et al. (8) have reported an increase in blood pressure and a decrease in plasma renin activity following $i c v$ choline injection. It has been concluded that the peripheral renin-angiotensin system does not participate in the effect of central cholinergic stimulation on blood pressure. Others have observed an increase in plasma renin activity due to intravenous (iv) injection of physostigmine, an indirect cholinomimetic agent (28). Since centrally administered cholinomimetics inhibit plasma renin activity by increasing VP secretion, it is not surprising that $i v$ physostigmine does not have the same effect.

The central relationship between the angiotensinergic and cholinergic systems in cardiovascular regulation is not fully understood. Therefore, the objective of the present study was to determine whether the increase in blood pressure due to central cholinergic stimulation would be changed by inhibition of the central renin-angiotensin system, using captopril, a specific and potent inhibitor of Ang II formation.

\section{Material and Methods}

Male Sprague-Dawley rats (Experimental Animals Breeding and Research Centre, Uludag University Medical Faculty, Bursa, Turkey) weighing 250-300 g were used in this study. Rats were housed 4-6 to a cage with food and water available ad libitum. The colony room was maintained at $20-24^{\circ} \mathrm{C}$ with a 12-h light-dark cycle.

The surgical and experimental protocols used were approved by the Animal Care and Use Committee of Uludag University.

Under ether anesthesia, rats were implanted through the right femoral artery with PE 50 tubing filled with heparinized saline (100 U/ml). For icv injections, a burr hole was drilled through the skull $1.5 \mathrm{~mm}$ lateral to the midline and $1-1.5 \mathrm{~mm}$ posterior to the bregma on the right side. Through this hole, a $10 \mathrm{~mm}$ length of 20 gauge stainless steel hypodermic tubing was directed toward the right lateral ventricle. The cannula was lowered perpendicularly $4-4.5 \mathrm{~mm}$ below the surface of the skull and fixed to the skull with acrylic cement.

Following the surgical procedure, rats were placed in individual cages and allowed to recover from anesthesia for at least $4 \mathrm{~h}$. During the recovery period, the animals showed no evidence of pain.

Following recovery, the arterial line was connected to a volumetric pressure transducer (Statham P23) and blood pressure was recorded continuously on a polygraph (Grass 7D model). Systolic blood pressure ( $\mathrm{mmHg}$ ) was recorded throughout the experiment. Control baseline recordings were obtained for $15 \mathrm{~min}$ before the drug injections.

In the first step, choline $(50,100$ or 150 $\mu \mathrm{g} / 10 \mu \mathrm{l})$ or saline $(10 \mu \mathrm{l})$ was injected $i c v$, in order to observe the effect of icv choline on blood pressure. In the second step, we investigated the involvement of the central renin-angiotensin system in the action of choline on blood pressure. For this purpose, rats were injected $i c v$ with the angiotensinconverting enzyme inhibitor captopril (25 or $50 \mu \mathrm{g} / 10 \mu \mathrm{l})$ or saline $(10 \mu \mathrm{l}) 3 \mathrm{~min}$ before $150 \mu \mathrm{g} i c v$ choline (the dose of choline to which a long-lasting blood pressure response was obtained).

At the end of the experiments, $5 \mu l$ of a methylene blue solution was injected into the cerebral ventricle through the cannula to confirm the placement of the inner end of the cannula. After decapitation, the brains were removed and sections were observed macroscopically to ascertain whether the cannula had been correctly placed into the lateral cerebral ventricle.

Choline chloride and captopril were obtained from Sigma Chemical Co. (St. Louis, MO, USA) and dissolved in saline. All doses of drugs refer to the free base in $10 \mu \mathrm{l}$ 
volume. Icv injections were performed using a Hamilton microsyringe.

Data are reported as means \pm SEM. Data were analyzed statistically by analysis of variance, with the level of significance set at $\mathrm{P}<0.05$.

\section{Results}

\section{Effect of icv choline on blood pressure}

In the saline-treated control group, no significant difference was found in the systolic blood pressure before and after saline injection (Figure 1). Also, $50 \mu \mathrm{g}$ choline did not produce a significant increase in blood pressure, except for an initial significant rise $(\mathrm{P}<0.05)$, which disappeared after a few minutes. In contrast, $100 \mu \mathrm{g}$ and $150 \mu \mathrm{g}$ choline induced an immediate and marked increase in blood pressure $(\mathrm{P}<0.01$ and $\mathrm{P}<0.001$, respectively). Ten minutes after $100 \mu \mathrm{g}$ choline injection, the increase in blood pressure was no longer significant compared to pretreatment values. On the other hand, $150 \mu \mathrm{g}$ choline induced a more significant and longlasting increase in blood pressure. Mean systolic blood pressure was $114 \pm 2.5 \mathrm{mmHg}$ before $150 \mu \mathrm{g}$ choline injection and significantly increased to $130 \pm 1.2 \mathrm{mmHg}$ within the second minute after the injection $(\mathrm{P}<0.001)$, followed by a value of $133 \pm 1.4$ mmHg 5 min later $(\mathrm{P}<0.001)$ and $136 \pm 1.7$ mmHg 10 min later $(\mathrm{P}<0.001)$. The blood pressure values were still significantly higher $(129 \pm 1.3 \mathrm{mmHg})$ during the 15 th minute $(\mathrm{P}<0.001)$. The values obtained 20 and 25 min after the injection did not differ significantly from pretreatment values.

\section{Role of icv captopril in the action of icv choline on blood pressure}

The angiotensin-converting enzyme inhibitor captopril given icv at a dose of $25 \mu \mathrm{g}$ did not affect blood pressure significantly (Figure 2). With $50 \mu \mathrm{g} i c v$ captopril a de- crease in blood pressure was observed, which was significant by the 10th minute after injection $(\mathrm{P}<0.05)$ and was followed by significantly lower values 15, 20 and 25 min after injection compared to pretreatment values $(\mathrm{P}<0.001)$.

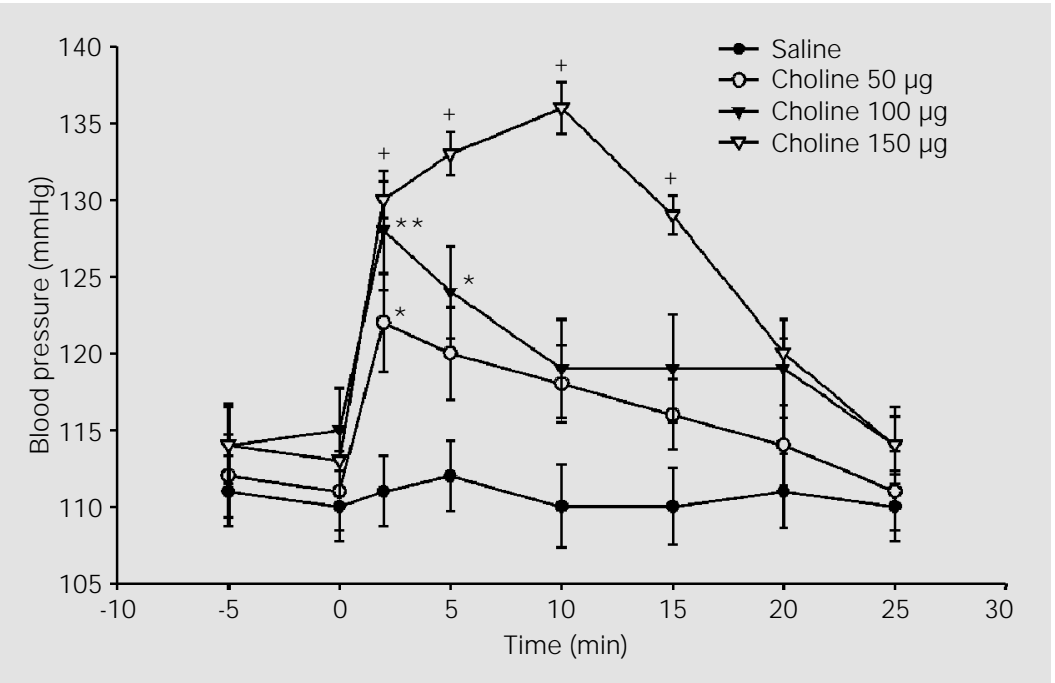

Figure 1. Effect of intracerebroventricular injection of choline on blood pressure in normotensive rats. Choline was injected at three doses $(50,100$, and $150 \mu \mathrm{g} / 10 \mu \mathrm{l})$ (time "0"), following baseline blood pressure recordings (time " -5 "). Data points indicate the mean \pm SEM for 7 rats. $* \mathrm{P}<0.05, * * \mathrm{P}<0.01$ and $+\mathrm{P}<0.001$ compared to pretreatment values (ANOVA).

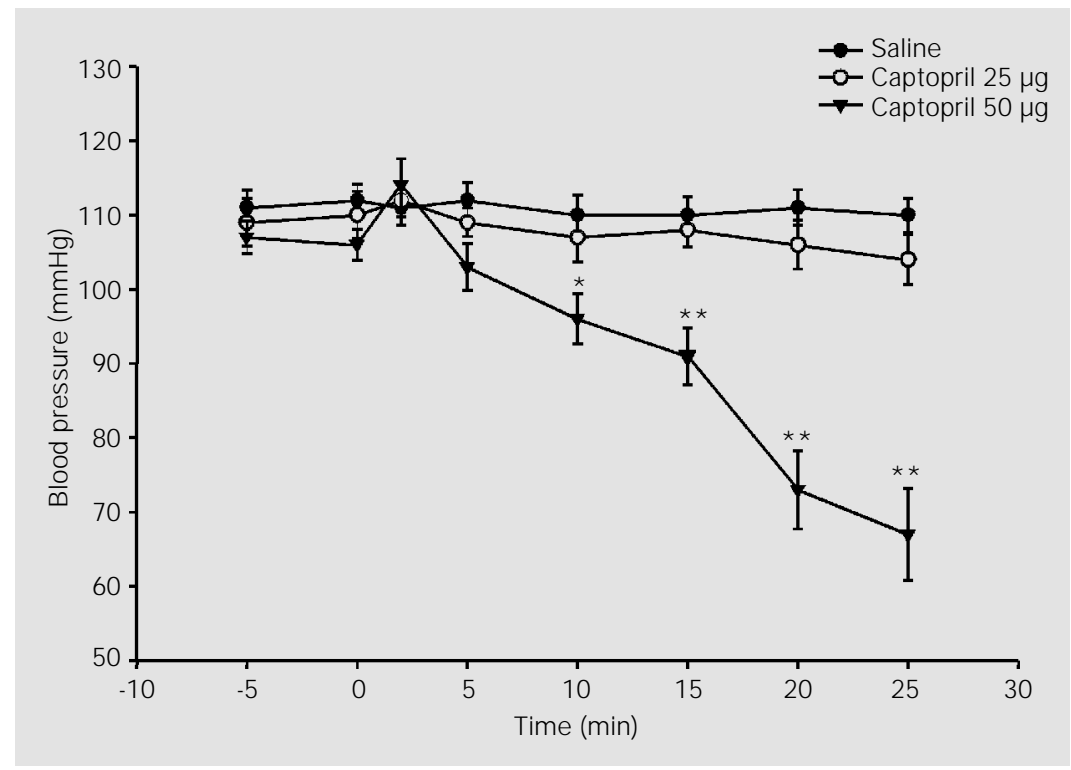

Figure 2. Effect of intracerebroventricular injection of captopril on blood pressure in normotensive rats. Captopril was injected at doses of 25 or $50 \mu \mathrm{g} / 10 \mu \mathrm{l}$ (time " 0 "), following baseline blood pressure recordings (time " -5 "). Values represent the mean \pm SEM for 7 rats. ${ }^{*} \mathrm{P}<0.05$ and $* * \mathrm{P}<0.001$ compared to pretreatment values (ANOVA). 
Previous injection of $25 \mu \mathrm{g}$ captopril (3 min) did not block the pressor response induced by $150 \mu$ g choline (Figure 3 ), with no difference compared to the saline $+150 \mu \mathrm{g}$ choline group. On the other hand, $50 \mu \mathrm{g}$ captopril significantly inhibited the blood pressure rise induced by $150 \mu \mathrm{g}$ choline $(\mathrm{P}<0.05$ and $\mathrm{P}<0.001) 2$ and 5 min after choline injection. Since $50 \mu \mathrm{g}$ captopril per se decreases blood pressure $10 \mathrm{~min}$ after injection, we analyzed the effect of captopril on choline-induced increase in blood pressure only during the first 10-min period. Indeed, the effect of choline on blood pressure was maximum throughout this corresponding period, decreasing slightly thereafter.

\section{Discussion}

Our results demonstrate that $i c v$ injected choline increases blood pressure in conscious, freely moving, normotensive rats. The effect of choline was dose- and timedependent under normotensive conditions, in agreement with previous studies. Previous studies have shown that centrally admin-

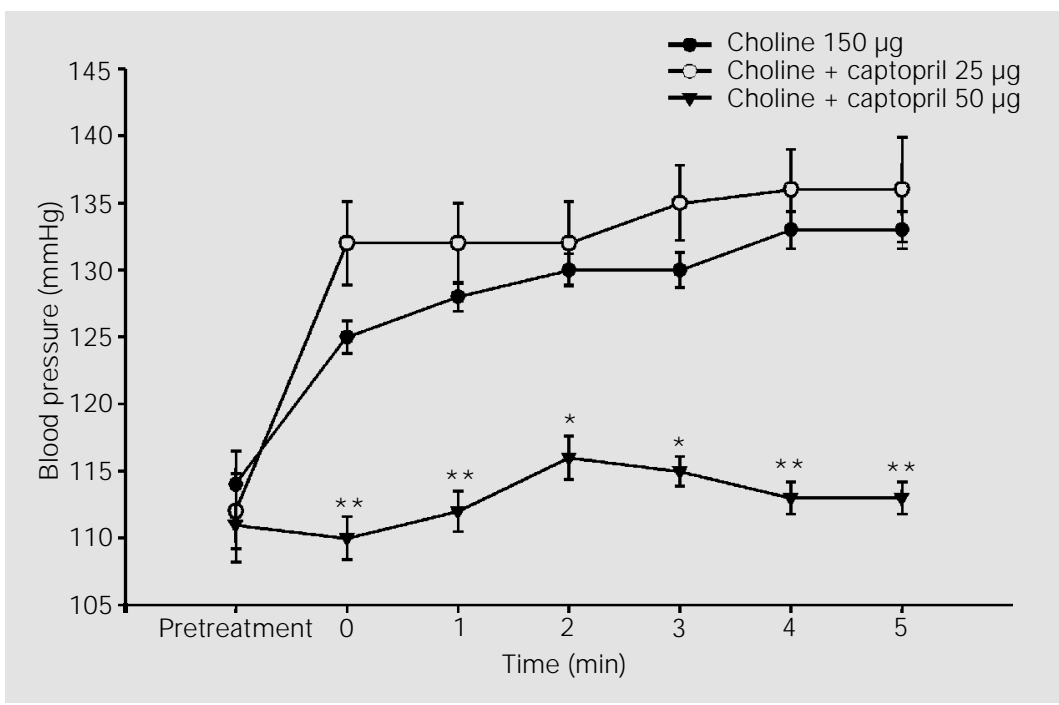

Figure 3. Effect of intracerebroventricular captopril ( 25 or $50 \mu \mathrm{g} / 10 \mu \mathrm{l}$ ) on blood pressure response to central choline $(150 \mu \mathrm{g})$ injection. Captopril was injected $3 \mathrm{~min}$ before choline. Time " 0 " represents the point of choline injection. Values represent the mean \pm SEM for 7 rats. $* \mathrm{P}<0.05$ and $* * \mathrm{P}<0.001$ compared to the saline $+150 \mu \mathrm{g}$ choline group (ANOVA). istered choline increases blood pressure in both normotensive and hypotensive rats. The pressor effect of choline on normotensive rats is lower and shorter $(5 \mathrm{~min})$ than that in hemorrhage-induced hypotensive rats $(2,4,8)$. The pressor effects of choline and other cholinomimetics on the cardiovascular system are associated with the sympathoadrenergic system and VP, as proven by the increase in both catecholamines and VP following central choline injection $(1,6,8)$.

Centrally administered Ang II also increases blood pressure and this effect is especially important in hypovolemic conditions $(12,15,16,19,29-31)$. Intracerebroventricular injections of renin-angiotensin system antagonists decrease blood pressure in spontaneously hypertensive and normotensive rats $(9,17,19,20,32,33)$. We also confirmed that captopril, an angiotensin-converting enzyme inhibitor, decreases blood pressure in a dose-dependent manner.

In the present study, we tried to determine the participation of the brain reninangiotensin system in the blood pressure response to central choline injections. Our results showed that the rise in blood pressure induced by choline was significantly reduced by prior central injection of $50 \mu \mathrm{g}$ captopril. We did not observe a similar effect with 25 $\mu \mathrm{g}$ captopril, which suggests that captopril dose-dependently inhibits the effect of centrally administered choline on blood pressure. The attenuation of the blood pressure response to $i c v$ choline did not seem to be related to the blood pressure-lowering effect of captopril, since captopril becomes significantly effective at the 10th minute following injection, as shown in Figure 2. Therefore we may interpret our data to indicate a central interaction of the renin-angiotensin system and the cholinergic system.

There are a number of reports concerning the relationship between these two systems but the results are contradictory. Moore and Drexler (29) have pointed out that $i v$ atropine sulfate and $i c v$ hemicholinium signifi- 
cantly inhibit the blood pressure response to icv Ang II. They have also reported that methyl atropine, which does not cross the blood-brain barrier, does not significantly inhibit the effect of icv Ang II on blood pressure and concluded that the inhibitory action of atropine itself might be centrally mediated.

Nicoletta et al. (22) have also shown that $i c v$ hemicholinium and $i c v$ atropine reduce the blood pressure increase induced by $i c v$ Ang II. Hemicholinium did not affect the Ang II-induced bradycardia, while high doses of atropine significantly reduced it. On the other hand, inhibition of the brain reninangiotensin system by $i c v$ captopril $(25 \mu \mathrm{g}$ and $50 \mu \mathrm{g}$ ) has been reported not to change the blood pressure and heart rate response to central physostigmine injection. The latter results are not consistent with our findings, since the brain renin-angiotensin system has not been considered to participate in the cardiovascular effects induced by either systemic or central cholinergic stimulation. The discrepancy between our results and those of Nicoletta et al. may be due to the different cholinergic system agonist and the different dosage used in the experiments, or to the different time of captopril injection.

In contrast, recent data have provided evidence supported by the present results. Saad et al. (34) have reported that central administration of losartan, an $\mathrm{AT}_{1}$-receptor blocker, and ramipril, a converting enzyme inhibitor, effectively blocks the pressor response induced by $i c v$ Ang II and icv carbachol. These investigators concluded that the pressor effects of Ang II and carbachol involve the central angiotensin system and $\mathrm{AT}_{1}$-receptor activation. In contrast, Hoffman and Phillips (35) suggested that angiotensin and carbachol act upon independent receptors in the brain to produce blood pressure and drinking responses, but at some point they share common central effector pathways. In fact, both systems involve the activation of vasopressinergic and sympathoadrenergic systems and this may account for their similar effects on blood pressure. We also suggest a participation of the central angiotensinergic system, at some point, in the action of the cholinergic system, since inhibition of Ang II formation dose-dependently blocked the blood pressure-increasing effect of choline.

In conclusion, our results suggest a role for the endogenous brain renin-angiotensin system in the blood pressure increase in response to $i c v$ choline in normotensive rats.

\section{References}

1. SinhaJ N, Dhawan KN, Chandra O \& Gupta GP (1967). Role of acetylcholine in central vasomotor regulation. Canadian J oumal of Physiology and Pharmacology, 45: 503507.

2. Srimal RC, J aju BP, Sinha J N, Dixit KS \& Bhargava KP (1969). Analysis of the central vasomotor effects of choline. European J ournal of Pharmacology, 5: 239244.

3. Brezenoff HE \& Caputi AP (1980). Intracerebroventricular injection of hemicholinium-3 lowers blood pressure in conscious spontaneously hypertensive rats but not in normotensive rats. Life Sciences, 26: 1037-1045.

4. Caputi AP \& Brezenoff HE (1980). Cardio- vascular effects produced by choline injected into the lateral cerebral ventricle of the unanesthetized rat. Life Sciences, 26: 1029-1036.

5. Brezenoff HE \& Giuliano R (1982). Cardiovascular control by cholinergic mechanisms in the central nervous system. Annual Review of Pharmacology and Toxicology, 22: 341-381.

6. Arslan BY, Ulus IH, Savci $V \&$ Kiran BK (1991). Effects of intracerebroventricular injected choline on cardiovascular functions and sympathoadrenal activity. J ournal of Cardiovascular Pharmacology, 17: 814-821.

7. litake K, Share L, Brooks DP, Crofton J T \& Ouchi Y (1989). Role of brain acetylcho- line in vasopressin release during osmotic stimulation and hemorrhage. Experimental Brain Research, 75: 47-52.

8. Ulus IH, Arslan BY, Savci $V \&$ Kiran BK (1995). Restoration of blood pressure by choline treatment in rats made hypotensive by hemorrhage. British J ournal of Pharmacology, 116: 1911-1917.

9. Berecek $K H$, Kirk KA, Nagahama $S \&$ Oparil S (1987). Sympathetic function in spontaneously hypertensive rats after chronic administration of captopril. American J ournal of Physiology, 252: H796H806.

10. Isaacson J S \& Reid IA (1990). Importance of endogenous angiotensin II in the cardiovascular responses to sympathetic 
stimulation in conscious rabbits. Circulation Research, 66: 662-671.

11. Matsukawa S, Keil LC \& Reid IA (1991). Role of endogenous angiotensin II in the control of vasopressin secretion during hypovolemia and hypotension in conscious rabbits. Endocrinology, 128: 204210.

12. Severs WB, Summy-Long JY \& Keil LC (1982). The brain renin-angiotensin system. Drug Development Research, 2: 231-239.

13. McKinley MJ, McAllen RM, Mendelsohn FAO, Allen AM, Chai SY \& Oldfield BJ (1990). Circumventricular organs: Neuroendocrine interfaces between the brain and hemal milieu. Frontiers in Neuroendocrinology, 11: 91-127.

14. Phillips MI, Speakman EA \& Kimura B (1993). Levels of angiotensin and molecular biology of the tissue renin angiotensin systems. Regulatory Peptides, 43: 1-20.

15. Bunnemann B, Fuxe K \& Ganten D (1993). The renin-angiotensin system in the brain: an update 1993. Regulatory Peptides, 46: 487-509.

16. Hoffman WE, Phillips MI, Schmid PG, Falcon J \& Weet J F (1977). Antidiuretic hormone release and the pressor response to central angiotensin II and cholinergic stimulation. Neuropharmacology, 6: 463472.

17. Cameron VA, Espiner EA, Nicholls MG, MacFarlane MR \& Sadler WA (1985). Intra-cerebroventricular captopril reduces plasma ACTH and vasopressin responses to hemorrhagic stress. Life Sciences, 38: 553-559.

18. Hjelmqvist $\mathrm{H}$, Ullman J , Hamberger B \& Rundgren M (1992). Cardiovascular and renal effects of intracerebroventricular angiotensin II in conscious sheep. Acta Physiologica Scandinavica, 145: 25-32.

19. Thunhorst RL \& J ohnson AK (1993). Effects of arterial pressure on drinking and urinary responses to intracerebroventricular angiotensin II. American J ournal of
Physiology, 264: R211-R217.

20. Gorbea-Oppliger VJ \& Fink GD (1995). Cerebroventricular injection of angiotensin II antagonist: effects on blood pressure responses to central and systemic angiotensin II. J ournal of Pharmacology and Experimental Therapeutics, 273: 611616.

21. Rohmeiss P, Beyer C, Nagy E, Tschöpe C, Höhle S, Strauch M \& Unger T (1995). $\mathrm{NaCl}$ injections in brain induce natriuresis and blood pressure responses sensitive to Ang II $\mathrm{AT}_{1}$ receptors. American J ournal of Physiology, 269: F282-F288.

22. Nicoletta $P$, Pochiero $M$, Losi E \& Caputi AP (1983). Interaction between renin-angiotensin system and cholinergic system in brain. Neuropharmacology, 22: 12691275.

23. Reid IA \& Chou L (1990). Analysis of the action of angiotensin II on the baroreflex control of heart rate in conscious rabbits. Endocrinology, 126: 2749-2756.

24. Lowes VL, McLean LE, Kasting NW \& Ferguson AV (1993). Cardiovascular consequences of microinjection of vasopressin and angiotensin II in the area postrema. American J ournal of Physiology, 34: R625-R631.

25. Toney GM \& Porter J P (1993). Effects of blockade of AT1 and AT2 receptors in brain on the central angiotensin II pressor response in conscious spontaneously hypertensive rats. Neuropharmacology, 32: 581-589.

26. Campagnole-Santos MJ, Heringer SB, Batista EN, Khosla MC \& Santos RAS (1992). Differential baroreceptor reflex modulation by centrally infused angiotensin peptides. American J ournal of Physiology, 32: R89-R94.

27. Colombari E, Saad WA, Camargo LAA, Renzi A, Luca LA \& Menani JV (1990). Role of central $\alpha_{1}$ - and $\alpha_{2}$-adrenoceptors on the dipsogenic and cardiovascular effect of angiotensin II. Pharmacology, Biochemistry and Behavior, 36: 893-896.
28. Alexandre J M, Menard J, Chevillard C \& Schmitt H (1970). Increased plasma renin activity induced in rats by physostigmine and effects of alpha- and beta-receptors blocking drugs thereon. European J ournal of Pharmacology, 12: 127-131.

29. Moore AF \& Drexler AP (1982). A cholinergic link in the centrally mediated actions of angiotensin II. Drug Development Research, 2: 241-250.

30. Velasco IT, Baena RC, Rocha E, Silva M \& Loureiro MI (1990). Central angiotensinergic system and hypertonic resuscitation from severe hemorrhage. American J ournal of Physiology, 259: H1752-H1758.

31. Lon S, Szczepanska-Sadowska E \& Szczypaczewska M (1996). Evidence that centrally released arginine vasopressin is involved in central pressor action of angiotensin II. American J ournal of Physiology, 270: H167-H173.

32. Clough DP, Hatton R, Keddie J R \& Collis MG (1982). Hypotensive action of captopril in spontaneously hypertensive and normotensive rats. Interference with neurogenic vasoconstriction. Hypertension, 4: 764-772.

33. Harding JW, J ensen LL, Quirk WS, Dewey AL \& Wright J W (1989). Brain angiotensin: Critical role in the ongoing regulation of body fluid homeostasis and cardiovascular function. Peptides, 10: 261264.

34. Saad WA, Luiz AC, Camargo LAA, Silveira JEN, Foglia S, Menani JV \& Saad WA (1997). Functional evidence that the central renin-angiotensin system plays a role in the pressor response induced by central injection of carbachol. Brazilian J ournal of Medical and Biological Research, 30: 493-496.

35. Hoffman WE \& Phillips MI (1977). Independent receptors for pressor and drinking responses to central injections of angiotensin II and carbachol. Brain Research, 124: 305-315. 